\title{
Hate Speech and Local Cultural Values in Indonesia
}

\author{
Oktavianus Oktavianus
}

\author{
Faculty of Humanities, University of Andalas \\ Padang, Indonesia \\ Email: oktavianus@hum.unand.ac.id
}

\begin{abstract}
Hate speech is the use of language in speech events that tends to hurt the social relationships among the speakers of the language. Observing the bad impact caused by hate speech, this study is an attempt to discuss hate speech and local cultural values in Indonesia. The study was conducted by using anthropolinguistic-pragmatic approaches. The data for this study is the use of hate speech in social and online media as well as YouTube. The responses of the interlocutor are used as the parameter to identify that an utterance is categorized as hate speech. The results of data analysis show that differences in views and ideologies tend to trigger hate speech among the speakers of the language. Besides, the result of the analysis also indicates that local cultural values have not been strong enough to prevent hate speech. Continuous revitalization of local cultural values and character building are needed to avoid using hate speech.
\end{abstract}

\section{Keywords: Language, Utterance, Hate Speech, Local Culture and Local Cultural Values}

\section{INTRODUCTION}

From the anthropolinguistic point of view, language is closely related to the culture and represents the culture of its speakers [1]; [2]). All local languages in Indonesia preserve cultural values which are expressed in various expressions and proverbs in those local languages. The Minangkabau language - one of the local languages spoken by the Minangkabau ethnic group in West Sumatera, for example, is rich in cultural values [3]; [4]; [5]). Lamak di awak, katuju di urang 'you have to respect someone if you want to be respected', sasakik, sasanang 'to be on the same boat', jauah cinto-mancintoi, dakek, jalang-manjalang 'out of sight but not out of mind' are some examples of expression having a positive cultural value in Minangkabau language. The Minangkabau language has also a highly valued politeness [6]. The Gayonese in Central Aceh has the concept of setie 'loyal' and semayang-gemasih 'love' [8]. The language of Batak Toba in North Sumatera preserves the idiom of holong mangalap holong 'render good for good' and the Sundanese has the expression of, silih asih, silih asah dan silih asuh 'to love each other, to improve one another, and to mutually protect' [7]. The language of Kei holds the expression, Rik luun, ne ham raan 'to share both heart and tear' [9].

Cultural values can be categorized into guided and unguided values [10]. The guiding values are all positive values that people should follow and the unguided values are all negative values that people should not follow. Owing to positive cultural values that every ethnic group in Indonesia should follow, it can be said that there is no room for hate speech in Indonesia. Nonetheless, there is still a lot of hate speeches found nowadays in many speech events. In addition, this study is to bridge up the guiding values in local culture into social life to avoid the practice of hate speech.

\section{METHODOLOGY}

This study applies anthropolinguistic-pragmatic approaches. The data for this study are text containing hate speech in online and social media. The data are also taken from YouTube. The data is collected through the non-participant observation method. For written data from online media, the screen-shot technique is used. The data from YouTube is orthographically transcribed. The analysis of data is done by relating the use of hate speech to guided cultural values. Meanwhile, the status of the utterances as the hate speech is identified by referring it to the context of language use and the reaction of the interlocutor.

\section{ANALYSIS AND DISCUSSION}

Pragmatically, the use of a language possibly triggers Face Saving Act (FSA) or Face Threatening Act (FTA), [11]. The FSA brings about a good relationship whereas FTA destroys social cohesion. FTA is usually caused by hate speech. In general, hate speech is the use of language to humiliate, harass, 
disdain ethnicity, race, physical shaming, blasphemy, and even to threaten the individual ethical autonomy [12]. However, the context plays an important role to define if there is any hate speech or not in the use of language. The following data illustrates how hate speech occurs in one speech event.

\section{Text A}

Aneh, kapal nanggala tenggelam yang didalamnya ada anshar thaghut semua sibuk mencari hadits tentang syahid nya orang yang meninggal karena tenggelam, oke hadits itu benar, tapi harus dilihat dulu lah aqidah nya bagaimana, apakah selama ini mereka telah menjalani islam secara kaffah? apakah mereka di barisan Allah atau dibarisan para musuh Allah? wallahu a'lam.

It is strange, the Nanggala sank there is anshar thagut inside it. All were busy searching for Hadits about the martyrdom of someone died of sinking. O.K. the hadith is correct, but first the aqidah has to be considered. Have they been practicing Islam perfectly so far ?. Were they in the frontline of Allah or in the frontline of the Allah's renegade? Allah knows it properlv

The context of text A above is the sinking of Submarine X. The news about the sinking of submarine $\mathrm{X}$ is so massive either on social media or on the electronic one. There is deep sorrow over the tragedy. However, there are responses to the tragedy that could be considered as hate speech as in the following sentences.

(a) Aneh, kapal nanggala tenggelam yang di dalamnya ada anshar thaghut.

It is strange, the Nanggala Submarine sank in which there is anshar thaghut inside it.

(b) Semua sibuk mencari hadits tentang syahidnya orang yang meninggal karena tenggelam.

All were busy searching for Hadits about the martyrdom of someone died of sinking.

(c) Ok hadits itu benar, tapi harus dilihat dululah aqidahnya bagaimana?' 'Ok.the hadith is correct but first the aqidah has to be considered'

(d) Apakah selama ini mereka telah menjalani islam secara kaffah?

'Have they been practicing Islam perfectly so far' (e) Apakah mereka di barisan Allah atau dibarisan para musuh Allah?

'Were they in the frontline of Allah or in the frontline of the Allah's renegrade?'

(f) Wallahu a'lam. Allah knows it properly.

Source: Social Media, 2021

Semantically, sentence (1a) states that there is anshar thaghut 'evil helpers' in the submarine X. Lexical choice such as the word aneh 'strange' and anshar thagut indicate that the sentence contains cynical statement to the sinking of submarine X. Sentence (1b) states that all are busy seeking for hadits (words of Prophet Muhammad) about the martyrdom of someone died of sinking. Sentences (1c), (1d) and (1e) question both faith and Islamicity of the crew of the Submarine $X$. Sentence (f) states that it is Allah who knows them. Sentences (1b) to (1f) also contain cynical statements about the sinking of submarine $\mathrm{X}$.

Ideological differences and the political situation in Indonesia which are sometimes associated with one's religion and religiosity trigger the use of hate speech. The term thaghut 'evil' as Quraish Shihab said is everything oppressing man-kind and misleading someone from the righteous path. In the text, the crew of submarine $\mathrm{X}$ are associated with Anshar thagut.

The statements in text A above can be categorized as hate speech for it might bring about resentment and hurt feelings. To identify that sentences (1a) to (1f) as the hate speech, we might read the interlocutor's reactions as follows.

\section{Text B (Responses to Text A)}

The reponse (Text $\mathrm{B}$ ) toward the text $\mathrm{A}$ above can be

ronaua
Thagut kapalo apak ang, maaf pak,
manggaritih wak baconyo, makan cari
hiduik sampai tacirik di Indonesia, nan
pemerintah yg mengelola negara dan
yang manjago negara di cacek nyo juo
1 hari suka Balas

analyzed as in the following sentences.
(a) Thagut kapalo apak ang 'Damn you'

(b) Maaf pak, manggaritih wak baconyo 'sorry, Sir, it fidgeted me to read it'

(c) Makan, cari hiduik sampai tacirik di Indonesia 
'eating, making living up to going to lavatory in Indonesia'

(d) Nan pemerintah yang mengelola negara dan yang menjago negara di cacek2 nyo juo

'Yet, you still found fault with the government managing and guarding the country'

Source: Social Media, retrived in 2021

Sentences (2a) to (2d) can be considered as expressions of anger and irritation as the effect of the statement in text A above. The semantic contents of Thagut kapalo apak ang 'damn you' is a very rude backlash toward the statements in text A. Generally, people could not accept and justify such statements expressed in text A. It is, too, supported by the public's negative responses address to the party producing the statements.

Recently, it has been found the preach contains hate speech delivered by someone. Parts of the statements can be seen below.

\section{Text C}

(a) Menurut saya setan terbesar di dunia apa? India, Bali, Cina, Korea .......

'I think, what is the biggest Satan in the world? India, Bali, Cina, Korea...'

(b) Dijemput setannya. Pakai sajenan.'

'The Satan is invited with sajenan.'

(c) Mengapa harus ngaben. Menghabishabiskan biaya....

'Why Should cremate. It is a coast wasting.'

(d) Orang $X$ ribet pakai sajenan.

The $\mathrm{X}$ is hectic having sajenan.'

Source: Youtube Penggalan ceramah DMD, retrived 2021).

The text C (3a-d) above are categorized as hate speech as it instigated people's emotion. The ethnic group which becomes the target of the preacher reacted severely and the preacher was strictly criticized and even made a laughing stock. It might be seen, too, in the comments appearing in social media almost all of which toned negatively.

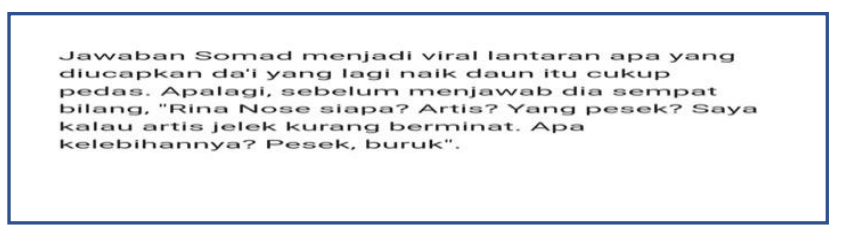

A Somad's answer was viral for what the wellknown preacher said was too rude. He even said, who is X ? An artist ? The Steep Nose? I do not like ugly artist. What is she better of ?
The hate speech through physical humiliating was also ever done by the preacher toward an artist making up her mind to unveil her yashmak. The text and reaction to such a case could be seen in the following data.

\section{Text D}

That text $\mathrm{D}$ above contains the hate speech can be traced in the following parts of sentences.

\begin{tabular}{|l|l|l|}
\hline (4) & (a) & $\begin{array}{l}\text { 'Rina Nose siapa? } \\
\text { 'Who is Rina Nose?' }\end{array}$ \\
\hline (b) & $\begin{array}{l}\text { Artis? } \\
\text { 'Artist?' }\end{array}$ \\
\hline (c) & $\begin{array}{l}\text { Yang Pesek? } \\
\text { 'The flat nose.' }\end{array}$ \\
\hline (d) & $\begin{array}{l}\text { Saya kalau artis jelek kurang berminat } \\
\text { 'The steep nose artist does not interest me' }\end{array}$ \\
\hline (e) & $\begin{array}{l}\text { Apa kelebihannya? } \\
\text { 'What is she better of? }\end{array}$ \\
\hline & (f) $\begin{array}{l}\text { Pesek, buruk'. } \\
\text { 'Flat (nose), ugly.' }\end{array}$ \\
\hline \multicolumn{2}{|l}{ Source: Suara.com, 20/11/2017, retrived in 2021 } \\
\hline
\end{tabular}

Pragmatically, the use of the word (hidung) pesek 'flat nose in (4c), artis jelek 'ugly artist' in (4d), and pesek buruk 'flat nose, ugly' in (4f) are the forms of physical humiliation.

That the utterances above contain hate speech can be seen from the response of the interlocutor as in the following data.

"Saya memang jelek, pesek, buruk dan tidak memiliki kelebihan apa-apa. Saya sudah tau sebelum anda mengatakannya," tulis Rina di caption.

"Tapi dengan segala keterbatasan dan kelemahan ilmu saya, saya tidak sampai hati mengatakan hal buruk tentang orang lain," sambungnya.

Source: Suara.com, 20/11/2017. Retrived, 2021

I am really ugly, steep Nose, bad, and nothing better of. I had known before you said it. "Rina wrote it in a caption".

\section{Text E (Responses to Text D)}

The reaction to the statement in the text $\mathrm{D}$ above was spoken up in humility but it preserved an ironic significance. It is a form of both annoyance and anger expressions to the statements in the text $\mathrm{D}$ as in the following sentences. 
(5) (a) Saya memang jelek, pesek, buruk dan tidak memiliki kelebihan apa-apa

'I am ugly, flat nose, and have nothing better of.

(b) Saya sudah tau sebelum Anda mengatakannya

'I had known it before you said it.'

(c) Tapi dengan segala keterbatasan dan kelemahan ilmu saya, saya tidak sampai hati mengatakan hal buruk tentang orang lain.

'but with all my foible knowledge, I do not have the heart to say bad things about other people'

Source: Suara.com. 20/11/2017, retrived in 2021

The text $\mathrm{D}$ above, triggered the negative reaction from both interlocutor and social media. As a response to the statement of the preacher in text $\mathrm{D}$, the physical form of preacher (dental structure) even became a laughing stock, too. An advisory scold and warning to the preacher can also be read in the following text.

\section{Text E (Responses to Text C)}

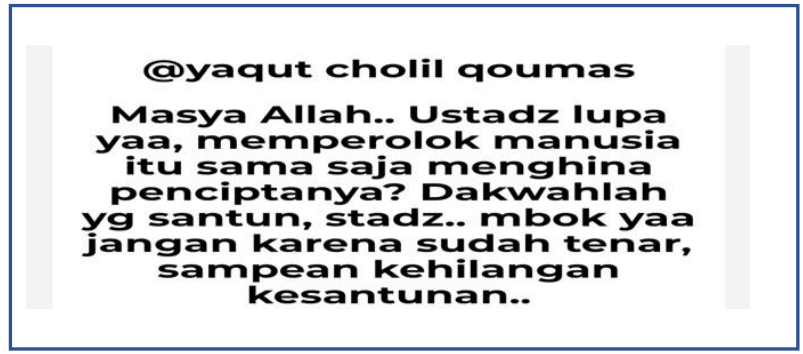

Oh my God, you forget, don't you? Making fun of the man-kind is just the same as insulting his/her Creator? 'Please have a modest propagation, Sir.' Do not lose your modesty due to your popularity

The analysis of the above text can be seen in the following description.

(6) (a) Masya Allah... ustadz lupa yaa, memperolok manusia sama saja dengan menghina penciptanya?

'Oh my God, you forget, don't you? Making fun of the man-kind is just the same as insulting his/her Creator'.

(b) Dakwahlah yg santun, stadz.

'Please have a modest propagation, Sir.'

(c) Mbok ya jangan karena sudah tenar, sampean kehilangan kesantunan

'Do not lose your modesty due to your popularity.'

The use of language in the text $\mathrm{D}$ above even contradicts the Malay morality and politeness written down in the (Malay) expressions below.

(7)
Yang kurik kundi
'What spotted is kundi.'
Yang merah saga
'What red is saga.'
Yang baik budi
'What good is courtesy.
Yang indah bahasa
'What beautiful is language.'

Comparing the statements in the text $\mathrm{D}$ above with Malay pantun in (7), it seems the use of language is not always in line with and refers to local cultural values. The local cultural values are not fully accommodated and well internalized yet. If local cultural values are accommodated and internalized, then, people may reduce or even eliminate the use of hate speech in their daily communication and interaction.

\section{CONCLUSION}

Based on the analysis of the data above, the text can be regarded as hate speech if the choices of words, phrases and sentences might trigger both resentment and anger that eventually brings about personal or other collective group hatred. The status of the statement as hate speech could be measured from the interlocutor's reaction or responses. If the response is negative, thus, the statements could be categorized a hate speech. However, the context also plays an important role in defining a status of a statement as hate speech. Then, the revitalization of the implementation of positive or guided cultural values needs to do sustainably to eliminate the use of hate speech.

\section{ACKNOWLEDGMENTS}

The author of this article would like to express deep thanks and appreciation to media online (suara.com), media social and YouTube channel of DMD for the use of language data in this study. The use of data from the sources mentioned here is solely for scientific purposes. The author is also indebted to Masyarakat Linguistik Indonesia (MLI) and Fakultas Ilmu Budaya Universitas Hasanuddin for all the efforts to publish this article in Atlantis Press.

\section{REFERENCES}

[1] Kramsch, C. (1998). Language and Culture. Oxford: Oxford University Press. 
[2] Duranti, A. (2013). Linguistic Anthropology. First published, Cambridge: Cambridge University Press.

[3] Nafis, A. (1996). Peribahasa Minangkabau. Jakarta: PT. Intermasa.

[4] Fanany, R., \& Fanany, I. (2003). Wisdom of the Malay Proverbs. Kuala Lumpur: Dewan Bahasa dan Pustaka.

[5] Oktavianus (2012). Kias dalam Bahasa Minangkabau. Padang: Penerbit Fakultas Ilmu Budaya. Universitas Andalas.

[6] Oktavianus dan Ike Revita. (2013). Kesantunan dalam Bahasa Minangkabau. Padang: Minangkabau Press.

[7] Oktavianus, (2016). 'Bahasa dan Kearifan Lokal sebagai Identitas Budaya”. Makalah Seminar Nasional di Fakultas Ilmu Budaya Universitas Sumatera Utara, 26 Oktober, 2016.

[8] Melalatoa, M. Junus. (1982). Kebudayaan Gayo. Jakarta: Balai Pustaka.

[9] Santosa, Imam Budhi. (2016). Peribahasa Nusantara: Mata Air Kearifan Bangsa. Jakarta: Penerbit PDIP.

[10] Djajasudarma, T. F. dkk, 1997. Nilai Budaya dalam Ungkapan dan Peribahasa Sunda. Jakarta: Pusat Pembinaan dan Pengembangan Bahasa, Departemen Pendidikan dan Kebudayaan.

[11] Thomas, J. (1995). Meaning in Interaction: An Introduction to Pragmatics. London: Longman.

[12] Waldron, Jeremy. (2012). The Harm in Hate Speech. USA: President and Fellows of Harvard College. 